\title{
Beyond Horizon: Miriam Toews's A Complicated Kindness and the Prairie Novel Tradition
}

\section{Claire Omhovère}

\section{(2) OpenEdition \\ Journals}

Electronic version

URL: https://journals.openedition.org/ces/8307

DOI: $10.4000 /$ ces.8307

ISSN: 2534-6695

Publisher

SEPC (Société d'études des pays du Commonwealth)

\section{Printed version}

Date of publication: 1 September 2010

Number of pages: $67-79$

ISSN: 2270-0633

\section{Electronic reference}

Claire Omhovère, "Beyond Horizon: Miriam Toews's A Complicated Kindness and the Prairie Novel Tradition", Commonwealth Essays and Studies [Online], 33.1 | 2010, Online since 11 December 2021, connection on 20 January 2022. URL: http://journals.openedition.org/ces/8307 ; DOI: https://doi.org/ $10.4000 /$ ces.8307

\section{cc)}

Commonwealth Essays and Studies is licensed under a Licence Creative Commons Attribution - Pas d'Utilisation Commerciale - Pas de Modification 4.0 International. 


\title{
Beyond Horizon: \\ Miriam Toews's $A$ Complicated Kindness and the Prairie Novel Tradition
}

\begin{abstract}
Although Miriam Toews's novels have garnered plaudits from prize committees all over North America, very little scholarly attention so far has been paid to the aesthetic dimension of her writing. Her novels, however, engage in thought-provoking ways with the Prairie novelistic tradition and the various strategies her predecessors have elaborated to turn indifferent space into inhabitable place. Aiming her narrator's wry humor at the "unique apartness" of the Mennonite community, Toews uses the incongruous as a discursive weapon to instill a sense of solidarity with the displaced and the marginal. In this respect, her writing is fully resonant with the anxieties of a national culture that endeavors to conjugate within the same space the claims of its minorities with the ethical aspirations of an increasingly diverse majority.
\end{abstract}

Here on the prairies we are always trying to name or generalize about an incomplete or fractured text. Facing the riddle of self, and community and horizon; we carefully mumble our answers. (Kroetsch "Defining” 211)

I mplicit in the very analogy the first European explorers perceived between the ocean they had just crossed and the Great Plains they were entering (Kreisel 258), the horizon line has been recurring in Prairie writing as the constitutive trait of a landscape defined by its minimalism: "Here was the least common denominator of nature, the skeleton requirements simply of land and sky - Saskatchewan prairie." (Mitchell 3) A genealogy of Prairie horizontality, and of the significations literature has vested in it, can thus be retraced from its inception in the early narratives of the British explorers to its constitution into a topos in the Prairie realism of the twentieth century. In Sinclair Ross's As for Me and My House (1941), Horizon designates a generic small town in the dusty Prairies of the Great Depression. Although the name still evokes the direction followed by the explorer's gaze and the desire to give shape to the new land, these significations only point to aspirations the characters fail to fulfill. Horizon has settled into a toponym with ironic connotations that do not intimate the diversity but the invariability of what lies ahead, the identical Main Streets and falsefronted buildings that await the minister and his wife on the Prairies' Bible belt (Ross 99-100). As their prospects narrow into myriad forms of imprisonment, the Bentleys' future slips behind them and becomes obliterated by an unsurpassable present:

I turned once and looked back at Horizon, the huddled little clutter of houses and stores, the five grain elevators, aloof and imperturbable, like ancient obelisks, and behind the dust clouds, lapping at the sky. 
It was like one of Philip's drawings. There was the same tension, the same vivid immobility, and behind it all somewhere the same sense of transience.

I walked on, remembering how I used to think that only a great artist could ever paint the prairie, the vacancy and stillness of it, the bare essentials of a landscape, sky and earth [.] (Ross 59, my emphasis)

The analogy with the sea is subdued but still active in the evocation of billowing dust clouds. Less formulaic is the far-fetched parallel between the town's grain elevators and "ancient obelisks." Mrs. Bentley's exacting eye detects a stark elegance in their verticality which projects an exotic monumentality onto the sparse setting. More than her thwarted intellectual ambitions, the narrator's reference to Ancient Egypt bespeaks Mrs. Bentley's inner contradictions. Her impatience with Horizon is mitigated with a sense of place which tentatively borrows its images from other climes in its search for an adequate idiom. Topophilia ${ }^{1}$ asserts itself in much more local terms three decades later with Wallace Stegner's influential memoir Wolf Willow (1962):

On that monotonous surface with its occasional ship-like farm, its atolls of shelter-belt trees, its level ring of horizon, there is little to interrupt the eye. Roads run straight between parallel lines of fence until they intersect the circle of the horizon. It is a landscape of circles, radii, perspective exercises - a country of geometry (6-7).

Viewed from above, the ubiquitous curve circumscribes the Prairies' seemingly infinite expanse and the adjustment of the correction lines necessary to force the rotundity of the earth to fit the square abstraction of the Dominion Land Survey. Put differently, the horizon embeds the gaze within the phenomenological world. It guides and stabilizes human perception in a space where, because few landmarks rise to oppose the propositions of the intellect, the eye may rove as far as the mind can see: "[T] he world is flat, empty, nearly abstract, and in its flatness you are a challenging upright thing, as sudden as an exclamation mark, as enigmatic as a question mark. It is a country to breed mystical people, egocentric people, perhaps poetic people. But not humble ones." (Stegner 8) In Stegner's rhapsodic prose, a specific landscape acquires its contours from the opposition between Prairie horizontality and the verticality of human constructs - the prosaic barns and hedges but also the verbal and metaphysical creations Man opposes to the leveling forces of the Prairies' extreme geography. Stegner is a central reference in both Laurie Ricou's Vertical Man/Horizontal World (1973) and Dick Harrison's Unnamed Country: The Struggle for a Canadian Prairie Fiction (1977), the first critical studies devoted to the formation of a regional literary tradition. References to Stegner's seminal influence continued to occur over the following decades in

1 The term was borrowed from Bachelard's poetic of space by cultural geographer Yi-Fu Tuan who defines it as "all of the human being's affective ties with the material environment" (93). 
theoretical writings concerned with the definition of a Prairie canon, particularly those of Robert Kroetsch. ${ }^{2}$ The postmodern avant-garde of the 1980s proposed their own reflections as regards the conundrum of place, the expression of a local pride, and the fostering of a sense of belonging. ${ }^{3}$ Writers as diverse as George Bowering, Rudy Wiebe or Aritha van Herk heralded a new age in Canadian writing with their robust irreverence towards the master-narratives inherited from old Europe, and their ear for local, vernacular cadences. It is therefore quite striking to see such preoccupations reassert themselves with some vehemence in recent fiction, as evinced by Miriam Toews's award-winning $A$ Complicated Kindness. ${ }^{4}$

The Prairie town Miriam Toews writes about lies in the rural Manitoba of the 1970s. Like so many other fictitious and real toponyms on the Prairies, Toews's "East Village" does not merely designate a place, but rather an attitude to place, an uneasiness in dwelling already perceptible in Ross's Horizon but also in Sharon Butala's "Ordeal," David Bergen's "Lesser," and even the authentic "Climax" rising like a fist against the flatness of the Saskatchewan grasslands. In Toews's novel, East Village lies sufficiently out west for its name to sound like a misnomer, or perhaps an error in translation. Indeed, the appellation indexes various forms of displacement including the nostalgia of its population, a community of Russian Mennonites forced into emigration by Stalin's persecutions. The younger generation, however, does not look east but south of the border. Nomi Nickel associates East Village somewhat subversively with its homonym in New York City, the hotbed of the 1960s counterculture which the young narrator embraces enthusiastically as an antidote against Mennonite disregard for the present. The opening chapter introduces the contradictions the sixteen-year-old has to face to come of age within a community suspicious of the worldly concerns that may divert its members from preparing for the advent of death, when the true believers will be taken home to Heaven to be reunited with their Maker ( $C K 4-5)$ In her determination to resist the entrapment of Mennonite doctrine and "escap[e] into the real world" (5), Nomi Nickel has to make sense of behaviours specific to the rigorous sub-sect her family belongs to, the most radical being the excommunication and ostracizing - the ritual shunning - to which the town's Elders subject free-thinkers. In the novel's incipit we therefore learn that Tash, the narrator's elder sister, and their mother Trudie preferred to leave East Village to spare their loved ones the sorrow of having to choose between their kin and their faith. As the novel unfolds, Nomi gradually pieces together the reasons why

2 See, in particular, "The Cow in the Quicksand and How I(t) Got Out: Responding to Wallace Stegner's Wolf Willow," in which Kroetsch explains that Stegner's memoir was one of the early texts that had enabled him to write. (Likely 66)

3 "The human response to this landscape is so new and ill-defined and complex that our writers come back, uneasily but compulsively, to landscape writing." (Kroetsch Lovely 5) 4 The paginations for all subsequent quotations from the novel will be given directly between parentheses in the body of the text. 
her sister and, later, her mother decided to leave East Village after each of them incurred the wrath of the community leader, aka The Mouth, on account of his partiality for Biblical bombast.

Ethnicity plays a decisive role in the novel, insofar as it adds considerable piquant to Nomi's story by raising the stakes of transgression. The confrontation of female derision with patriarchal sternness is redoubled in the burlesque treatment of Mennonite fundamentalism. In this context, however, the wielding of humour is not without pitfalls:

I have realized that my personal yearning to be in New York City, wandering around with Lou Reed in Greenwich Village, or whatever, is for me a painful, serious, all-consuming kind of thing and is for the rest of the world a joke. When you're a Mennonite you can't even yearn properly for the world because the world turns that yearning into comedy. It's a funny premise for a movie, that's all. Mennonite girl in New York City. Amish family goes to Soho. It's terribly depressing to realize that your inner most desires are being tested in Hollywood for laughs per minute. (CK 135)

What distinguishes A Complicated Kindness from the productions of the entertainment industry ${ }^{5}$ is its serious investigation of the relationship between mainstream culture and minority subculture. Toews addresses this aspect in two distinct ways: first by carefully inserting her version of a Mennonite childhood into the Prairie horizontal tradition, and second through a systematic use of humour which deflates the pathos of victimhood and includes the marginal within a community of sentiment.

Nomi's yearning for the world owes much of its ironical trenchant to the fact that its voicing originates from within a group renowned for the literal understanding and strict application of the religious principles its members abide by. Literal-mindedness, more than any other trait, is the implicit target of many Canadian jokes deriding Mennonite sternness. The point is made by Nomi when she recalls her sister exclaiming: "We're a national joke, she'd say. Seriously, she'd say, we're the joke town in the joke province in the joke country." (71) Underlining that Canadians do not fare much better in the eyes of their self-confident American neighbours than Manitobans in regard to Ontarians, and Mennonites in respect to everyone else, Tash's remark ironically relates her own uncertainties about communal allegiance to wider anxieties about national and regional status. In fact, some of the ethnic peculiarities presented in Toews's novel often seem like paroxystic, exaggerated versions of regional or national traits. Even if the archaic custom of shunning is presented as the Mennonite response to dissent, exclusion is by no means a strictly Mennonite practice. Prairie

5 Although it is not a comedy, the lasting fame of Peter Weir's Witness (1985) confirms the fascination of audiences with the quaint ways of the Anabaptists and the transgressive potential of any contact between their pacific ideal of virtue and the lewd violence of modernity. 
literature abounds with examples of characters ostracized for having questioned the principles of religious fundamentalism, or rebelled against the rules imposed by a community whose presence is perceived as both comforting and intrusive. In this sense, the complicated kindness Toews's characters display towards one another finds its analogue in many other Prairie novels. The Nickel women come up against a self-righteousness which is not essentially different from the criticism some of the characters need to fight off in Mitchell's Who Has Seen the Wind. But whereas a Miss Thompson ultimately prevails and stays on, Tash and Trudie Nickel have to abide by the collective decision and leave. The way the community leader interferes with Trudie Nickel's privacy is not without similitude with the control exerted by the Ladies Auxiliary in Who Has Seen the Wind (Mitchell 46-48) or the Ladies Aid, their equivalent in As for Me and my House (Ross 132). The shopkeeper that watches over Nomi and keeps the count of her visits to church finds her match in the vigilance surrounding the child in van Herk's Places Far from Ellesmere (1990) where absolute visibility in Edberg's open landscape is resented as a form of vulnerability (van Herk 14). Exposure to public scrutiny explains the importance of the back door in Prairie collective life, an aspect the fictitious Rita Kleinhart investigates in her poetry, much to the resentment of her own neighbours (Kroetsch Poetics 12-13).

Yet Prairie horizontality does not allow the same lines of flight in $A$ Complicated Kindness as it does in other Prairie works. In Ross's novel, Mrs. Bentley could indeed seek relief from Horizon's scrutiny - and boredom - during a brief excursion to the open range. Half a century later, van Herk sets off with all her characters on a radical northern journey to Ellesmere Island. As for Rita Kleinhart, like so many of Kroetsch's characters slipping over the horizon into new lives, she flies to Europe and disappears in the Frankfurt Museum of Modern Art. Nomi's prospects suffer in comparison. A Complicated Kindness looks back on the 1970s, a period when movement became increasingly disengaged from any actual physical displacement. Nomi and her friends trip on weed, magic mushrooms, or any other substance available at "the pits." In mock-Bunyan fashion, the allegorical name designates the pond where the local youth courts eternal damnation, fighting off the despondency caused by lack of perspective:

Saturday nights you'd have a hundred or more kids down there drinking, dropping, smoking, swearing, screwing, fighting, swimming, home-made tattooing, passing out and throwing up right up until an hour or so before church the next morning when everyone would be back in the pew with Mom and Dad wearing nice (ugly) dresses and buttoned-up shirts flipping through Deuteronomy and harmonizing to "The Old Rugged Cross'” (CK 34)

The parallel lists of present participles underline that the pits and the church are the obverse and the reverse of the same excess, although the rhythm of the period slows down dramatically as Saturday frenzy rearranges itself into Sunday piety. 
As for the city, it still exists but only as a remote possibility whose gleaming lights Nomi contemplates as they pop up on the evening horizon. In fact, the information age has brought urban temptations, and sins, into the heart of the country. Broadcast on the radio and the television, smuggled into books and LPs, the waves of pop culture crash over East Village, shaking the foundations of Mennonite "unique apartness." (CK 148) In reaction to the outside world, the small town opposes its economic self-sufficiency. Most of the population finds employment in the local shops and services, at the Museum village where they impersonate their ancestors' past occupations in period costume, or at the chicken slaughterhouse, the Elders' only concession to modernity: "The artificial village and the chicken evisceration plant a few miles down the road are our main industries. [...]. There are no bars or visible exits." (53) Punning on the double entendre of the plural "bars," the last sentence draws attention to the paradox of a topography which is simultaneously open and closed because it refuses the distractions of the present and, along with them, the very possibility of change. By denying the world its interest, by reinvesting it in the Kingdom to come, Mennonite doctrine short-circuits the dynamics of disappearance and re-invention so central to Prairie writing, from the novels of F. P. Grove to Robert Kroetsch's fiction and poetry.

In A Complicated Kindness, departure is not the solution but the problem, the initial complication which sets the narrative into motion. Indeed, for the characters, the difficulty does not lie in leaving and reinventing a life for themselves, but rather in staying and living together, preferably in the same place:

I live with my father, Ray Nickel, in that low brick bungalow out on highway number twelve. Blue shutters, brown door, one shattered window. Nothing great. The furniture keeps disappearing though. That keeps things interesting.

Half of our family, the better-looking half, is missing. (1)

The book opens like a crime novel recording a mysterious disappearance. Yet the sensational parallel between dilapidated house and mutilated family is somewhat undercut by the boredom oozing from the description. The subsequent chapters continue to toy with the conventions of the detective story, but the central mystery - What happened to Tash? Where did Trudie end up? - becomes peripheral to the unfolding of narrative. As Nomi puts together the circumstances that led to her sister's and her mother's exclusions, her reconstruction does not point to a vanishing point. Neither does it identify an ultimate destination. Tash's whereabouts will remain unknown, and no one will ever discover whether Trudie opted for suicide or exile. The same holds for Ray Nickel when he finally departs from his by then empty home, and leaves his younger daughter poised on the threshold of adulthood, ready to leave her deserted home but still hesitating. For each character, the possibilities of re-invention remain as open as the blank pages on Trudie's passport, a leitmotiv confirming the narrator's claim that she has no 
talent for devising endings. And indeed, we are not offered a climactic revelation but something different - the anatomy of a decomposition.

Although the appeal of distant horizons survives in Nomi's New York fantasies, the characters' departures are less often deliberate than imposed on them. Leaving becomes clearly secondary to the difficulty of staying together and remaining part of a community threatened with dissolution. In the novel's allegorical topography, two places call for attention as landmarks in the formation and disintegration of the Nickel family. There is the sewage lagoon where Nomi's father allegedly proposed to her mother (156), and the local dump Ray Nickel visits on a regular basis, especially since Trudie has vacated the family home. Yet, none of these sites is imbued with the chaotic fertility, the creative messiness often associated with waste in North American literature, whether in the valley of ashes of Fitzgerald's Great Gatsby (1925) or in Wallace Stevens's "Man on the Dump" (1938), as well as in the garbage heaps which attract the outcast and the eccentric in Margaret Laurence's The Stone Angel (1964) and Alice Munro's Lives of Girls and Women (1971). "The dump was kind of like a department store for Ray, but even more like a holy cemetery where he could organize abandoned dreams and wrecked things into families, in a way, that stayed together." (CK 159) It is not the living forces of decomposition which add a grotesque dimension to the scene, but rather the mock heroic elevation transforming dumping ground into sacred ground, and the stubborn refusal to let a life go down the drain and chaos prevail. Ray Nickel insists: "I organize the garbage in a way I feel makes sense." (158) The remark has a metafictional ring suggesting that Ray's insistence on cohesion and meaning-making may well be relevant to the stylistic strategies the novel deploys to address such issues as the cohesion of the community and its tolerance for difference.

Nomi's erratic bike-rides constitute a convenient - because flexible enough - narrative thread to string together the sketches and memories that constitute the novel. These involve the neglected child next door, the former teenage rebel returned to the fold of shopkeeping, the widow mourning the early loss of her son, the old lady of the infected leg and broken English, etc. With their amused attention to local foibles and quirks but also their graphic account of genuine loss and pain, these portraits recall the ironic benevolence W. O. Mitchell shows for his characters in Who has Seen the Wind, ${ }^{6}$ and Kroetsch's grotesque humour in What the Crow Said (1978), much more than Rudy Wiebe's sentimental evocation of another Prairie childhood in Sweeter than All the World. Closer to Brian O'Connal than to the young Adam Wiebe on their way to discover the world, Nomi learns from her fellow human beings the difficulty of leading a responsible life, and the

6 The narrator responds to the Prairie wind in lyrical terms that clearly allude to W.O. Mitchell's great classic: "I could smell the wind coming through the open window behind her and it was like a present or a compliment or something." (CK 59) 
value of sympathy. Toews, however, does not preach, and pathos - although the book does contain some - is held in check by the wry humour of the narrator:

Main Street is as dead as ever. There's a blinding white light at the water tower end of it and Jesus standing in the centre of it in a pale blue robe with his arms out, palms up, like he's saying how the hell would I know? I'm just a carpenter. He looks like George Harrison in his Eastern religion period working for Ringling Brothers. Whatever amateur made the sign put a red circle on each of his cheeks to make him look healthy, I guess, but healthily ridiculous. On the other end is another giant billboard that says Satan is real. Choose now.

Main Street is bookended by two fields of dirt that never grow a crop. They lie in perpetual fallow, my dad told me. Those words haunt me still.

I can sense that Americans who come here think it's strange. Main Streets should lead somewhere other than to eternal damnation. They should be connected to something earthly, like roads. ( $C K 47$, my emphasis)

When an exasperated Mrs. Bentley derides Horizon's fundamentalism in Sinclair Ross's novel, she appeals to reason to discriminate between fact and figure of speech. Her pragmatic remarks on the absurd weight of Noah's alleged cargo place her in the position of a seventeenth-century libertine who, although unable to disprove the existence of God, still claimed the right to have rational doubts about it (Ross 111). Nomi, on the contrary, does not confront fundamentalism head on with the arguments of an outsider. Hers is the insider's strategy, also known as sabotage. Because she is fully aware of the impact of monological discourse, the persuasiveness of the statement which says what it says, Nomi extends the Elders' literal interpretation of the Scriptures to the description of the world around her ad absurdum. Accordingly a statue of Jesus is Jesus just as Satan is real. The literal register, as a result, encroaches upon the figurative, bringing an additional, concrete signification to the images the narrator uses. The burlesque analogy between Jesus and George Harrison, once it has been posited, will subsequently be used literally, obliterating the initial referent: "I said goodbye to everyone I passed and trudged towards the outstretched arms of George Harrison." (60) Following the same logic, stating that "East Village is dead" no longer sounds like a trite, because dead, metaphor. In fact, the adjective strikes the reader as more than apt to describe the population's life-long waiting for the Last Judgment. Nomi's use of the figurative register systematically involves a literal doubling which grounds the spiritual in her prosaic surroundings. Main Street is "bookended" in more than one sense, the most immediate referring to the Holy Bible which encompasses all aspects of the inhabitants' existence. Sticking to the premise that there is no essential difference between the image and what it serves to represent, Nomi causes the logic of the literal to inflate and reach absurd extremities, as in the punch line which reroutes the metaphysical, bringing eternal damnation level with the surrounding horizon.

An identical effect is achieved through collage. On one of her aimless bike rides, Nomi takes a mental note of the sign outside the church, and one paragraph 
further, passes along the local store's advertising banner. The juxtaposition of the two messages reads as follows:

AND THEY SHALL GO FORTH, AND LOOK UPON THE CARCASSES OF THE MEN THAT HAVE TRANSGRESSED AGAINST ME : FOR THEIR WORM SHALL NOT DIE, NEITHER SHALL THEIR FIRE BE QUENCHED ; AND THEY SHALL BE AN ABHORRING UNTO ALL FLESH. [...] COME ON IN AND CHECK OUT OUR NEW MEAT DEPARTMENT. (CK 154)

Because the capital letters stand out on the page, the two excerpts tend to read like a single syntagm whose second half would be the consequence of the first one, in a logical consequence of the post hoc, ergo propter hoc fallacy. ${ }^{7}$ The juxtaposition conveys the infernal vision of human bodies neatly wrapped up in cellophane, ready for purchase and consumption. The suggestion is not as preposterous as it sounds, as it is perfectly integrated in a cluster of images describing The Mouth and, by extension, the small town as ravenous ogres. ${ }^{8}$ Here, Nomi's literalisation of the meaning of the Scriptures operates on two distinct levels. The symbolic and somewhat cryptic signification of Isaiah $66: 24$ has its field of reference displaced from damnation into the kitchen, which produces a ludicrous conflation between sinner and Sunday roast. In true Swiftian fashion, this grotesque proposal contains a more modest yet much more outrageous suggestion. By placing church and store on the same plane, Nomi indicts a form of religious marketing which derives its profit from the commodification of fear and guilt wrapped up in liberal quantities of hypocrisy:

[The Mouth]'s in love with the notion of shame and he traffics the shit like a schoolground pusher, spreading it around but never personally using. He's not a fire-and-brimstone guy. That's not really our speed. Too animated. Too much like dancing. ( $C K$ 49)

The punch line is a variation upon the well-known Mennonite joke - why do Mennonites object to having sex standing up? The similitude posited between preaching, dancing and sex (for those aware of the joke's antecedents) is characteristic of Nomi's rhetorical deviousness, which subverts the literal register by reintroducing ambivalence and semiotic slippage in reference to beliefs and

\footnotetext{
7 "As Roland Barthes argues in "Introduction à l'analyse des récits," the groundwork of narrating is the confusion between consecutiveness and consequence. We inevitably tend in any sequence to interpret what come after as having been caused by. " (Dvorak 66) 8 As, for instance, in the following: "[The Mouth] had so many large grey teeth. Some were jagged, some pointy, like a mountain range"; "the seriously ugly little buildings lining Main Street like a mouthful of rotten teeth"; "the kind of kid[s] a town like this chews up and spits out every day like happy hour"(83, 222, 245 respectively). This, of course, ties in with the ominous prospect of the poultry abattoir, a graphic threat to all feather-brained young ladies.
} 
principles of conduct which tolerate no such play, as any doubling, ambiguity or imitation is considered to be fraught with the duplicity of the devil.

Although Nomi has a wicked sense of humour, her portrait of East Village and Mennonite ways does not rankle into a bitter denunciation of the wrongs perpetrated in the name of virtue. The debunking of religious hypocrisy is a prominent aspect of the novel, yet serious satire is not made to prevail over comic irreverence. ${ }^{9}$ This is mainly due to the narrator's use of the burlesque which debases the sacred and substitutes for its vertical hierarchy the horizontal plane of the mundane world where all things co-exist and can be envisaged through their interrelations instead of in terms of superiority or inferiority. ${ }^{10}$ This horizontal leveling is essential for two reasons. First, it participates in the comic effects which, in this novel, have a reconciling rather than a chastising function, impressing upon readers that Toews's characters are guided by the same motivations as the rest of mankind. This leveling consequently undermines the separateness Mennonites claim for themselves, a "unique apartness" (CK 148) premised on a strict observance of rules: "[In East Village] there's no room for in between. You're in or you're out. You're good or you're bad. Actually very good or very bad. Or very good at being very bad without being detected." $(10)^{11}$ The syntactic reshuffling of contraries causes exclusory categories to blur, thus introducing a form of convergence, or in-betweenness, where the orthodoxy posits absolute distinctions.

Incongruous comparisons are another means for Nomi to question the separation between good and evil, the sacred and the profane, the local and the exotic, Mennonites and the rest of the world. The popular successes of the seventies, for instance, suggest to Nomi a wealth of similes to comment on the particularity of her people. There is no better evocation of the Mennonites' plight, she parenthetically notes, than the Rolling Stones' Exiles on Main Street (CK 137). Later, she borrows from Bob Dylan a famous refrain to illustrate the relation between Mennonites and Hutterites: "They are another sub-sect of our larger clan, except they live in colonies. Kibbutz-style. We are all, though, knock, knock, knocking on heaven's door. The same door." (133) The kibbutz reference has comic potential because, beyond the allusion to Dylan's origins, the Hebrew word introduces some ecumenical confusion between two religions which, in their own special way, are both wary of polluting contacts with the exterior. A similar dynamic can

9 Nomi alludes to the frequency of domestic violence (39), and denounces the economic advantages of being a conscientious objector in times of war (68).

10 This substitution is in keeping with Bakhtin's analysis of grotesque realism in popular culture and the transfer of top to bottom that constitutes the human body into the relative center of the cosmos (Bakhtin 364).

11 The repetition and transgressive permutations are reminiscent of van Herk's rearrangement of the list of forbiddances and allowances in the autobiographical Places Far from Ellesmere (22-23). 
be observed in Nomi's recurrent choice of exotic similes to describe local curiosities: "Everything in this town, the school, the church, the museum, the chicken plant, is connected to everything else, like the sewers of Paris"; "The administration passed her round for beatings like a hookah pipe at a Turkish wedding", and the open sore on Mrs. Klippenstein's leg, "ooz[ing] night and day, like Vesuvius" $(183,152,163)$. The narrative thus abounds in unexpected combinations connecting elements that belong to distinct spaces, different genres or incompatible registers: "what constitutes a problem is not the thing, or the environment where we find the thing, but the conjunction of the two; something unexpected in a usual place (our favourite aunt in our favourite poker parlour) or something usual in an unexpected place (our favourite poker in our favourite aunt)." (Winterson 45)

The surprise caused by the incongruous is a source of transgressive pleasure because it tests the plasticity of English syntax and its capacity for combinations that challenge norms and the expectancies they construct. As Winterson's mischievous permutations illustrate, the incongruous calls attention to the horizon of common understanding against which signification detaches itself, statements making sense in relation to a standard usage and a specific context. In this sense, toying with the incongruous without lapsing into nonsense is a faculty which can only be enjoyed by those at home in the language:

[Mrs. Klippenstein's] English wasn't very good. One time I told her she was lucky she didn't have to go to school (we'd been discussing my assignments) and she grabbed my arm and said I'll eat your heart out. She said things like slice me open a bun and throw me down the stairs a face cloth.

Trudie and I would try not to laugh. (163)

Laughing, however, is what the implied reader is encouraged to do in solidarity with characters who delight in the polysemy of the English language - the puns that combine several meanings within one signifier, ${ }^{12}$ but also the creative misunderstandings that attest to the vagaries of the interpretation and the plurality of meaning it leads to.

Although Toews's narrator introduces herself as "Nomi from Nowhere" (56), the small town portrayed in A Complicated Kindness has been carefully mapped by her literary predecessors, who have conjoined the investigation of self with the investigation of place. In this sense, Toews's novel does come from somewhere, a literary tradition which links together the biographical with the geographical: How do you grow a poet? How do you grow a Prairie town? The questions first formulated in Kroetsch's poem "Seed Catalogue," later recurring in his theoretical essay "The Moment of the Discovery of America Continues" root the creative voice in a specific rural milieu the constitutive lacks and absences of which allow

12 The book abounds in examples that would have delighted Lewis Carroll as, for instance, when Nomi's parents comment on the depth of the adverb "well" (43). 
the poet to speak the world anew. In different yet complementary ways, Rudy Wiebe and Aritha van Herk have eloquently written of the endless expanse of Prairie space, its immensity calling for voices powerful and plural enough to make its vacancy resonate with possibilities. As for Toews, she places the emphasis less upon Horizon and the limitations of the local than upon the horizontal relations through which individuals bond into communities. Her strategies of incongruous literalization challenge the verticality of patriarchal hierarchy and spiritual authority. Miriam Toews uses humour to sabotage Mennonite seriousness but also to instil a sense of solidarity with the displaced and the marginal. In this respect, her writing is fully resonant with the anxieties of a national culture that endeavours to conjugate within the same space the claims of its minorities with the ethical aspirations of an increasingly diverse majority.

Claire OMHOVÈRE Université Montpellier 3

\section{Works Cited}

BaкнтіN, Mikhail. Rabelais and his World. Trans. Helen Iswolsky. Bloomington, IN: Indiana UP, 1984.

Bergen, David. A Year of Lesser. New York: Haper, 1996.

Butala, Sharon. The Fourth Archangel. Toronto: HarperPerennial, 1993.

Dvorak, Marta. Ernest Buckler: Rediscovery and Reassessment. Waterloo: Wilfrid Laurier UP, 2001.

FitzGerald, F.S. The Great Gatsby. 1925. Oxford, New York: OUP, 1998.

Harrison, Dick. Unnamed Country: The Struggle for a Canadian Prairie Fiction. Edmonton: U. of Alberta P, 1977.

Kreisel, Henry, "The Prairie: A State of Mind." Contexts of Canadian Criticism: A Collection of Critical Essays. Ed. Eli Mandel. 1968. Chicago: U of Chicago P, 1971. 254-266.

Kroetsch, Robert. What the Crow Said. Toronto: PaperJacks, General Publishing, 1979.

-. Completed Field Notes: The Long Poems of Robert Kroetsch. Toronto: McClelland \& Stewart, 1989.

-. The Lovely Treachery of Words: Essays Selected and New. Toronto, New York, Oxford: Oxford UP, 1989.

—. A Likely Story: The Writing Life. Red Deer, AB: Red Deer College P, 1995.

-. The Hornbooks of Rita K. Edmonton: U of Alberta P, 2001.

—. "Don't Give Me No More of Your Lip; or, The Prairie Horizon as Allowed Mouth." Toward Defining the Prairie. Region, Culture and History. Ed. Robert Wardhaugh. Winnipeg: U of Manitoba P, 2001. 209-215. 
Laurence, Margaret. The Stone Angel. 1964. Chicago: U of Chicago P, 1993.

Mitchell, W.O. Who Has seen the Wind. 1947. Toronto: Macmillan Canada, 1960.

Munro, Alice. Lives of Girls and Women. 1971. Harmondsworth: Penguin, 1982.

Ricou, Laurie. Vertical Man/Horizontal World. Vancouver: UBC P, 1973.

Ross, Sinclair. As for Me and My House. 1941. Toronto: McClelland \& Stewart, 1957.

STEGner, Wallace. Wolf Willow: A History, a Story, and a Memory of the Last Plains Frontier. 1962. Harmondsworth: Penguin, 1990.

Toews, Miriam. A Complicated Kindness. London: Faber \& Faber, 2005.

Tuan, Yi-Fu. Topophilia, A Study of Environmental Perception, Attitudes and Values. Englewood Cliffs, NJ: Prentice-Hall, 1974.

Van Herk, Aritha. Places Far from Ellesmere. Red Deer, AB: Red Deer College P, 1990.

WIEBE, Rudy. Sweeter than All the World. Toronto: Knopf, 2001.

Winterson, Jeanette. Oranges Are not the Only Fruit. London: Pandora P, 1985. 